\title{
Effect of the application of biostimulants on the agronomic parameters of corn varieties ${ }^{1}$
}

\author{
Athir Husham Mahdi Al-Temimi ${ }^{1 *} \odot$, Intsar Hadi Hamadi Al-Hilfy²® \\ ${ }^{1}$ Ministry of Agriculture, Agricultural Research Department, Baghdad, Iraq. E-mail: atheer.hesham1006@coagri.uobaghdad.edu.iq \\ ${ }^{2}$ University of Baghdad, College of Agricultural Engineering Sciences, Baghdad, Iraq. E-mail: entsar.hadi@coagri.uobaghdad.edu.iq
}

ABSTRACT: The use of large quantities of mineral fertilizers causes many environmental problems. The aim of this study was to study the effect of minerals, organic and bio-fertilizers on yield and it's components of three synthetic varieties of maize and the possibility of replacing part of the mineral fertilizers with organic or bio-fertilizers. The layout of the experiment was Randomized Complete Blocks Design in split plots arrangement with three replicates. The experiment included three synthetic varieties of maize in the main plots and five fertilizer treatments in the sub plots. The results showed that maize varieties had non-significant difference in all studied characters except the number of rows per ear; Baghdad-3 gave the highest mean of the number of rows per ear $\left(14.98\right.$ row ear $\left.^{-1}\right)$. Also, the results indicated that there were significant differences among fertilizer treatments in all studied characters, the application of 50\% mineral fertilizer + spraying seaweed extract at $10 \%$ had the highest means of number of ears per plant (1.43 ear plant $\left.{ }^{-1}\right)$, number of rows per ear (15.08 row ear $\left.{ }^{-1}\right)$, number of grains per row $\left(39.34\right.$ grain row $\left.^{-1}\right)$ which led to highest grain yield $\left(9077 \mathrm{Kg} \mathrm{ha}^{-1}\right)$, while the application of mineral fertilizer as recommended gave the highest mean of 500 grain weight $(111.78 \mathrm{~g})$.

Key words: fertilizer; seaweed extract; yield; Zea mays

\section{Efeito da aplicação de bioestimulantes}

\section{nos parâmetros agronômicos de variedades de milho}

RESUMO: $O$ uso de grandes quantidades de fertilizantes minerais causa muitos problemas ambientais. 0 objetivo deste trabalho foi estudar o efeito de fertilizantes minerais e orgânicos e biofertilizantes na produtividade e seus componentes de três variedades sintéticas de milho e a possibilidade de substituir parte dos fertilizantes minerais por fertilizantes orgânicos ou biofertilizantes. 0 experiment foi conduzido em um delineamento em blocos completes casualizados com parcelas subdivididas e três repetições. O experimento incluiu três variedades sintéticas de Milho nas parcelas principais e cinco tratamentos de fertilizantes nas subparcelas. Os resultados mostraram ausência de efeito significativo das variedades de milho para todas as características estudadas exceto 0 número de linhas por espiga, em que Baghdad-3 apresentou a maior média (14,98 filas espiga- $\left.{ }^{-1}\right)$. Os resultados também indicaram diferenças significativas entre tratamentos de fertilizantes para todas as características estudadas, com a aplicação de $50 \%$ de fertilizante mineral + pulverização de extrato de algas marinhas a $10 \%$ apresentando as maiores médias de número de espigas por planta (1,43 espigas planta-1 $\left.{ }^{-1}\right)$, número de linhas por espiga $\left(15,08\right.$ linha espiga- $\left.^{-1}\right)$, número de grãos por linha (39,34 grãos linha-1) levando a maior produtividade (9077 $\left.\mathrm{Kg} \mathrm{ha}^{-1}\right)$, enquanto a aplicação de fertilizante mineral segundo a recomendação levou à maior média de peso de 500 grãos $(111,78 \mathrm{~g})$.

Palavras-chave: fertilizante; extrato de alga marinha; produtividade; Zea mays

\footnotetext{
${ }^{1}$ Part of Ph.D. dissertation of the first author. Work presented at the 1st International Conference on Agricultural Sciences - Virtual (1st ICAS-V, 2020)

*Athir Husham Mahdi Al-Temimi - E-mail: atheer.hesham1006@coagri.uobaghdad.edu.iq (Corresponding author)

Associate Editor: Mário de Andrade Lira Júnior
} 


\section{Introduction}

The highest yield can be obtained when there is a suitable compatibility between the genotypes and growth factors available such as nutrients add to crops. Maize is a C4 plant, which responds to large amounts of mineral fertilizers, so there are attempts to replace part of these large amounts of mineral fertilizers with safe alternatives by applying a clean agriculture system or organic and biological farming to obtain good quality of yield, preserving the amount of yield per unit area and preserving environmental factors from pollution. The recent studies indicated a possibility reduced $50 \%$ of the recommended mineral fertilizers by replacing them with organic and bio-fertilizers (Al-Hilfy \& Al-Temimi, 2017). The researchers believe that the use of algae of all kinds as active organic fertilizers is better than mineral fertilizers, as they are a natural source that is environmentally friendly, biodegradable, in addition to low cost and not polluted or harmful to human and animal health as compared with the excessive use of mineral fertilizers that harm the fertility of the soil and cause a lot of problems for farmers (AlKhayyat, 2004; Abdel Hamid, 2008; Kightlinger et al., 2012). Seaweed extract contains all trace elements (Devi \& Mani 2015; Pal et al., 2015) and some content plant hormones such as auxins, gibberellins and cytokines (Zhang \& Ervin 2008; Lotze \& Hoffman, 2016), Therefore, using it may led to significant increase in yield of some crops due to improving plant metabolism function (Zhang \& Ervin 2008; Wang et al., 2016). From other hand, Malusà et al. (2016) emphasized that the bio-fertilizers have the ability to give a similar yield to the mineral fertilizers, i.e. they have an important role in the nutrient management system in agricultural soils and reducing the negative impacts of mineral fertilizer on the environment. Also, Abasi et al. (2011) reported that the biofertilizers, fungal (MAF) or bacterial, have a positive effect on the growth and yield of maize as well as content of nutrient especially nitrogen and phosphorous, and noted that adding fungi and bacteria together was more effective in absorbing nutrients compared with adding each of them separately. So, because of the above the present study was designed to determine the effect of mineral, organic and bio-fertilizers on yield and it's components of three synthetic varieties of maize and the possibility of replacing part of mineral fertilizers with organic or bio-fertilizers.

\section{Materials and Methods}

A field experiment was carried out during Autumn season of 2019 from July 2019 to December 2019, at Field Crops Department - College of Agricultural Engineering Sciences University of Baghdad, Iraq, located at latitude of 33‥32' N and longitude of 440.23' $\mathrm{E}$ in a sandy loam soil as show their physical and chemical properties in Table 1.

The layout of the experiment was Randomized Complete Blocks Design in split plots arrangement with three replicates. The experiment included three synthetic varieties of maize
Table 1. Physical and chemical soil properties.

\begin{tabular}{ccc}
\hline Trait & Value & Unit \\
\hline Sand & 37.20 & \\
Loam & 49.66 & $\%$ \\
Clay & 13.14 & \\
Ec & 3.30 & $\mathrm{dS} \mathrm{m}^{-1}$ \\
pH & 7.12 & \\
Available N & 20.11 & $\mathrm{mg} \mathrm{L}^{-1}$ \\
Available P & 8.35 & \\
Available & 80.71 & \\
\hline
\end{tabular}

\{Bohooth-5018 (V1), Baghdad-3 (V2) and Sumer (V3)\} in the main plots and five fertilizer treatments in the sub plots, which were:

1. (Control) Application of mineral fertilizer according to recommendation (T1).

2. Application of $50 \%$ mineral fertilizer + spraying seaweed extract at $5 \%(\mathrm{~T} 2)$.

3. Application of $50 \%$ mineral fertilizer + spraying seaweed extract at $10 \%$ (T3).

4. Application of $50 \%$ mineral fertilizer + seeds pollution with Azotobacter chroococcum + Glomus mosseae (T4).

5. Application of $50 \%$ mineral fertilizer + seeds pollution with Pseudomonas flourescens + Glomus mosseae (T5).

Soil managements especially plowing were carried out as required, the net area of sub Plot was ( $3 \mathrm{~m}$ long $\times 4 \mathrm{~m}$ width) $12 \mathrm{~m}^{2}$ which contained 4 rows, $0.75 \mathrm{~m}$ apart and $0.25 \mathrm{~m}$ within the plants. A distance of $1 \mathrm{~m}$ was left between the experimental units and $1.5 \mathrm{~m}$ between the replicates. The seeds of three synthetic varieties of maize were sown on $16^{\text {th }}$ July 2019 at a rate 53333 plant ha-1. The algae extract (Spirulina algae) which properties are shown in Table 2 . was prepared by taking 10 grams of dried powder and soaked in $100 \mathrm{ml}$ of distilled water, after which it is placed in the autoclave for 30 minutes, and then it is cooled and filtered using a piece of cloth, and thus we obtain a liquid algae extract at a concentration $100 \%$ (Mohanty \& Adhikary, 2018). The required concentration of the liquid extract is prepared according to the dilution formula. was spraying at three times (4, 8 and 12 leaves stages)

The bacterial biological fertilizer consisting of two isolates of bacteria, Azotobacter chroccocum and Pseudomonas fluorescens, was prepared by preparing a medium suitable for their growth, and the day before planting, the bacteria were injected into the growth medium, and kept under appropriate conditions (low temperature) until the time of use and 30

Table 2. Content of liquid Spirulina extract from nutrients and growth regulators.

\begin{tabular}{ccc}
\hline Trait & Value & Unit \\
\hline $\mathrm{N}$ & 23 & \\
$\mathrm{P}$ & 80 & $\mathrm{mg} \mathrm{L}^{-1}$ \\
$\mathrm{~K}$ & 392 & \\
$\mathrm{Na}$ & 412 & \\
$\mathrm{Ca}$ & 163 & \\
Auxins & 8 & $\mu \mathrm{g} 100 \mathrm{~g}^{-1}$ \\
Gibberellins & 95 & \\
Cytokines & 184 & \\
\hline
\end{tabular}


minutes before planting was done. Treating planting seeds with biological fertilizers at $10 \mathrm{~g}$ of bio-fertilizer per $1 \mathrm{~kg}$ of seeds and homogenized well by adding gum arabic at a ratio of 1:10 (Bahrani, 2015). As for the Mycorrhizae fungus G. mosseae, which consisted of dry soil, the spores and the infested Mycorrhizae roots, was added at once in contact with the seeds inside the planting pit at a rate of $10 \mathrm{~g}$ per pitch.

Recommended nitrogen fertilizer was applied as a urea $(46 \% \mathrm{~N})$ with an average $300 \mathrm{Kg} \mathrm{ha}^{-1}$ in two equal doses $(1 / 2$ at six leaves stage and $1 / 2$ after 30 days of the first dose), whereas phosphorus fertilizer (300 Kg ha-1) as super triphosphate $\left(46 \% \mathrm{P}_{2} \mathrm{O}_{5}\right)$ and potash fertilizer $\left(225 \mathrm{Kg} \mathrm{ha}^{-1}\right)$ as a potassium sulfate $\mathrm{K}_{2} \mathrm{SO}_{4}(45 \% \mathrm{~K})$ were applied at the time of planting (Mnajid \& Oiyed, 2013) Crop managements were carried out as needed, and the plants were harvested after the appearance of maturity signs.

At harvest time, samples of 10 plants were taken from two central rows in each plot when harvested to measure the number of ears plant ${ }^{-1}$, number of rows ear ${ }^{-1}$, number of grains row ${ }^{-1}$ and 500 grain weight. Grain yield (ton ha-1) was calculated after manual threshed of 10 plants of two rows of each plot and then the grain weight was converted from g plant ${ }^{-1}$ to ton ha ${ }^{-1}$ with save moisture content (14\%). The recorded data were statistically analyzed according to the analysis of variance at $p>0.05$ by using the GenStat software. The least significant difference (LSD) was used to compare calculated average of studied traits (Steel \& Torrie, 1980).

\section{Results and Discussions}

\section{Number of ears per plant}

The results in Table 3 indicate that there were nonsignificant differences among maize varieties in the number of ears per plant. While the effect of fertilizer treatments was significant and the application of $50 \%$ of mineral fertilizer with spraying of seaweed extract at $10 \%$ (T3) had the highest mean (1.43 ear plant $\left.{ }^{-1}\right)$ without significant difference with the application of $50 \%$ of mineral fertilizer with seeds pollution of Azotobacter chroococcum + Glomus mosseae (T4) (1.33 ear plant $\left.^{-1}\right)$, whereas the application of mineral fertilizer as recommended ( $\mathrm{T} 1$ ) and the application of $50 \%$ mineral fertilizer with spraying of seaweed extract at $5 \%$ (T2) had the lowest means ( 1.23 ear plant ${ }^{-1}$, respectively). The reason of the superiority of $\mathrm{T} 3$ treatment may be attributed to the fact that it contains adequate amounts of plant growth regulators such as auxins, gibberellins, cytokines, and necessary nutrients for plant growth and development (Table 2), which made it a good fertilizer source, in addition to balance of nutrients absorption by the plant caused by spraying seaweed extracts during critical stages of plant growth. Also, the application of $50 \%$ mineral fertilizers reduced the negative effect resulting from adding large amounts of mineral fertilizers, (which increases the soil $\mathrm{pH}$ and an reduces the absorption of available nutrients) (Mohanty et al., 2013). From other hand, the bio-fertilizers had direct role in increasing the roots and their spread area which mean an increasing roots ability to absorb the largest
Table3. Effect of fertilizer treatments on the number of ears per plant of maize varieties.

\begin{tabular}{ccccc}
\hline Fertilizer/ & \multicolumn{3}{c}{ Varieties } & \multirow{2}{*}{ Mean } \\
\cline { 2 - 4 } Treatments & V1 & V2 & V3 & \\
\hline T1 & 1.23 & 1.26 & 1.20 & 1.23 \\
T2 & 1.23 & 1.23 & 1.23 & 1.23 \\
T3 & 1.40 & 1.46 & 1.43 & 1.43 \\
T4 & 1.33 & 1.36 & 1.30 & 1.33 \\
T5 & 1.30 & 1.33 & 1.23 & 1.28 \\
LSD 0.05 & & N.S. & & 0.10 \\
Mean & 1.30 & 1.33 & 1.28 & \\
LSD 0.05 & & N.S. & & \\
\hline
\end{tabular}

amount of nutrients, reflected positively in the increase of dry matter and thus stimulate the growth and development of secondary ears (Bashan \& de Bashan, 2010). These results are in agreement with Alousi \& Elsahookie (2006) which indicated that the sink strength in the maize varieties which have more than one ear was increased when the nutrients are available in appropriate amounts and available absorption by the plant. The interaction between two factors had non-significant effect on the number of ears per plant (Table 3 ).

\section{Number of rows per ear}

Regarding the number of rows per ear, the results in Table 4 showed significant differences among maize varieties in the number of rows per ear, the Baghdad-3 variety (V2) gave the highest mean (14.98 row ear ${ }^{-1}$ ) without significant difference with the Sumer variety (V3) (14.78 row ear ${ }^{-1}$ ), while the Bohooth-5018 variety (V1) gave the lowest mean (14.48 row ear $\left.^{-1}\right)$. This is due to their genetically components and their response to the environmental conditions. The number of rows per ear was significantly affected by fertilizer treatments (Table 4), the T3 treatment recorded the highest mean (15.08 row ear ${ }^{-1}$ ) without significant difference with the T4 treatment (14.86 row ear $\left.{ }^{-1}\right)$, while the $\mathrm{T} 2$ treatment recorded the lowest mean (14.48 row ear $\left.{ }^{-1}\right)$. The reason of an increasing the number of rows per ear may be attributed to the richness of seaweed extracts in macro and micro nutrients in addition to their content of plant growth regulators, especially cytokines, andoleic acid and gibberellins, and these have an effective role in increasing the yield by supporting plant nutrition, which is reflected in increase the leaf area, which in turn leads to an increase in the accumulation of dry matter. It also works to increase the percentage of pollination and fertilization by reducing the decrease the rate of ovules abortion (Zhang \& Ervin, 2008; Wang et al., 2016), as the availability of nutrients at this stage, especially nitrogen, leads to an increase in the size of ear. The number of rows in ear and the number of grains per row are determined at this stage, which is reflected in the increase in the grain yield. The reason may also be attributed to the ability of the biological fertilizers represented by the fungus Glomus mosseae to absorb nitrogen, phosphorous, potassium, calcium, sulfur, iron, manganese, copper and zinc from the soil and transfer these nutrients to the plant through the roots. These results are in agreement with Wuhaib et 
Table 4. Effect of fertilizer treatments on the number of rows per ear of maize varieties.

\begin{tabular}{ccccc}
\hline Fertilizer/ & \multicolumn{3}{c}{ Varieties } & \multirow{2}{*}{ Mean } \\
\cline { 2 - 4 } Treatments & V1 & V2 & V3 & \\
\hline T1 & 14.86 & 14.46 & 14.66 & 14.66 \\
T2 & 14.26 & 14.80 & 14.40 & 14.48 \\
T3 & 14.73 & 15.40 & 15.13 & 15.08 \\
T4 & 14.33 & 15.20 & 15.06 & 14.86 \\
T5 & 14.20 & 15.06 & 14.66 & 14.64 \\
LSD 0.05 & & N.S & & 0.36 \\
Mean & 14.48 & 14.98 & 14.78 & \\
LSD 0.05 & & 0.25 & & \\
\hline
\end{tabular}

al. (2009) and Sharifi \& Taghizaden (2009) who indicated that the number of rows per ear increased by increasing the availability of nutrients at the different stages of plant growth. The interaction between the two factors had non-significant effect in this trait.

\section{Number of grains per row}

Data in Table 5 showed that there were no significant differences among maize varieties and the interaction between two factors in the number of grains per row, while the effect of fertilizer treatments was significant, the T3 treatment had the highest mean (39.34 grain row $^{-1}$ ) without significant difference with the (T5) treatment (38.11 grain row ${ }^{-1}$ ), whereas the T1 treatment had the lowest mean (37.13 grain row $\left.^{-1}\right)$. This superiority may be due to the role of organic extracts and biofertilizers in increasing the products of photosynthesis process and transfer to the sinks and increasing the percentage of pollination and fertilization, which led to increase in the number of grain (Wuhaib et al., 2009), as well as their role in increasing the availability of nitrogen, which regulate the action of hormones and control the action of auxin in bringing about the apical dominance of the ear, the cytokines prevent the transfer of auxins from the old grains to the new grains and then increase the proportion of the florets fertility(Mohana et al., 2015), which positively affected on the number of grains per ear.

Table5. Effect of fertilizer treatments on the number of grains per row of maize varieties.

\begin{tabular}{ccccc}
\hline Fertilizer/ & \multicolumn{3}{c}{ Varieties } & \multirow{2}{*}{ Mean } \\
\cline { 2 - 4 } Treatments & V1 & V2 & V3 & \\
\hline T1 & 37.57 & 36.30 & 37.53 & 37.13 \\
T2 & 38.03 & 37.83 & 37.77 & 37.88 \\
T3 & 39.33 & 39.40 & 39.30 & 39.34 \\
T4 & 36.87 & 38.70 & 37.90 & 37.82 \\
T5 & 38.73 & 37.17 & 38.43 & 38.11 \\
LSD 0.05 & N.S & 1.44 \\
Mean & 38.11 & 37.88 & 38.19 & \\
LSD 0.05 & \multicolumn{4}{c}{ N.S } \\
\hline
\end{tabular}

\section{0 grain weight $(\mathrm{g})$}

Table 6 reveals no significant differences among maize varieties and interaction between two factors. However, there was significant effect among fertilizer treatments, the T1 treatment gave the highest mean) $111.78 \mathrm{~g}$ ) without significant
Table 6. Effect of fertilizer treatments on the 500 grain weight of maize varieties $(\mathbf{g})$.

\begin{tabular}{ccccc}
\hline Fertilizer/ & \multicolumn{3}{c}{ Varieties } & \multirow{2}{*}{ Mean } \\
\cline { 2 - 4 } Treatments & V1 & V2 & V3 & \\
\hline T1 & 111.00 & 115.00 & 109.33 & 111.78 \\
T2 & 107.67 & 106.67 & 110.33 & 108.22 \\
T3 & 106.00 & 100.33 & 104.00 & 103.44 \\
T4 & 116.33 & 101.00 & 109.33 & 108.89 \\
T5 & 107.33 & 106.67 & 105.67 & 106.56 \\
LSD 0.05 & N.S & & 5.35 \\
Mean & 109.67 & 105.93 & 107.73 & \\
LSD 0.05 & \multicolumn{5}{c}{ N.S } \\
\hline
\end{tabular}

difference with the T4, T2 and T5 treatments (108.89, 108.22 and $106.56 \mathrm{~g})$, respectively, whereas the T3 treatment gave the lowest mean (103.44 g). The reason for the superiority of the treatment T1 may be attributed to the relative decrease in the yield components represented by the number of ears in the plant, the number of rows in the ear, and the number of grains per row, which led to the accumulation of dry matter obtained by the plant from the process of photosynthesis and its collection in a smaller number of sinks, which was reflected in the increase in the weight of the kernel. It should be noted that the increase in the weight of the kernel did not compensate for the decrease in the number of ear per plant and the number of kernels in the ear, which was reflected in the decrease in the total grain yield.

\section{Grain yield (Kg ha-1)}

The results in Table 7 showed that no significant differences among maize varieties and their interaction with fertilizer treatments in the grain yield, while the grain yield Data was significantly affected by fertilizer treatments, the T3 treatment recorded the highest mean (9077 $\mathrm{Kg} \mathrm{ha}^{-1}$ ) with an increase $13.51 \%$ compared with control treatment (T1) and the T2 treatment which recorded the lowest mean (7850 $\mathrm{Kg} \mathrm{ha}^{-1}$ ). The application $50 \%$ of mineral fertilizer with spraying of seaweed extract at $10 \%$ (T3) had provided maize plants with macro and micro nutrients, in addition to plant growth regulators, especially cytokines, indole acetic acid and gibberellins, which have an effective role in increasing the yield components (Tables 3, 4 and 5 ) by supporting the plant nutrition and then increased the grain yield. These results are in agreement with Singh et al. (2015) who found an increase

Table 7. Effect of fertilizer treatments on the grain yield $(\mathrm{kg}$ $\mathrm{ha}^{-1}$ ) of maize varieties.

\begin{tabular}{ccccc}
\hline Fertilizer/ & \multicolumn{3}{c}{ Varieties } & \multirow{2}{*}{ Mean } \\
\cline { 2 - 4 } Treatments & V1 & V2 & V3 & \\
\hline T1 & 8055 & 7946 & 7549 & 7850 \\
T2 & 7653 & 7783 & 7759 & 7732 \\
T3 & 8886 & 9145 & 9202 & 9077 \\
T4 & 8440 & 8373 & 8486 & 8433 \\
T5 & 8034 & 8295 & 7723 & 8017 \\
LSD 0.05 & & N.S & & 555 \\
Mean & 8214 & 8308 & 8144 & \\
LSD 0.05 & & N.S & \\
\hline
\end{tabular}


in the grain yield of maize when sprayed with seaweed. From other hand, these results mean the possibility of reducing the amount of mineral fertilizers $50 \%$ of the recommendations when spraying algae extract at $10 \%$ concentration, thus we have reduced the negative impact of the mineral fertilizers on the ecosystem and human health by $50 \%$, and in economic terms we saved $50 \%$ of the production costs resulting from adding large amounts of mineral fertilizers.

\section{Conclusions}

The fertilizer treatment T3 gave the best results, as its superiority in the trait of the number of ear per plant, the number of rows in ear, the number of grains per row and the total grain yield, and the response differed according to the varieties included in the study.

Fertilizer treatment $\mathrm{T} 1$ gave the highest weight of the kernel.

The treatments $\mathrm{T} 4$ and $\mathrm{T} 5$ superiority the grain yield on the control treatment.

\section{Compliance with Ethical Standards}

Author contributions: Conceptualization: IHHAI-H; Data curation: AHMAI-T; Formal analysis: AHMAl-T; Funding acquisition: AHMAI-T, IHHAI-H; Investigation: IHHAI-H; Methodology: AHMAI-T, IHHAI-H; Project administration: AHMAI-T; Resources: AHMAI-T, IHHAI-H; Software: AHMAI-T; Supervision: IHHAI-H; Validation: AHMAI-T; Visualization: AHMAI-T; Writing - original draft: AHMAI-T; Writing - review \& editing: AHMAI-T, IHHAI-H.

Conflict of interest: There is no conflict of interest with other parties

Funding: Researchers, Faculty of Agricultural Engineering - University of Baghdad, and the Agricultural Research Department - Ministry of Agriculture.

\section{Literature Cited}

Abasi, A.; Zarea, M.J.; Rejali, F.; Barari, M. Effects of $P$ solubilizer bacteria and AM fungi on forage maize growth in a semi-arid region in Iran. Journal of Agricultural Technology, v.7, n.3, p.589597, 2011. https://doi.org/10.4067/S0718-95162013005000040.

Abdel Hamid, A. The use of algae in agriculture and medicine. Cairo: Helwan University; Faculty of Sciences; Department of Botany and Microbiology, 2008. p.78-54..

Al-Khayyat, S. Use of algae as a conditioner for desert and reclaimed lands. Riyadh: King Saud University; College of Science Research Center for Science; Departments and Medical Studies, 2004. p.81-96.

Al-Hilfy, I.H.H.; Al-Temimi, A. H. M. Response of some synthetic maize cultivars tomineral,organic and bio fertilizer , 1 - Yield and its components. The Iraqi Journal of Agricultural Sciences, v.48, n.6, p.1447-1455, 2017. https://jcoagri.uobaghdad.edu.iq/index. php/intro/article/view/266. 22 Jun. 2020.
Alousi, A.A.; Elsahookie, M.M. Hybrid-inbred response of maize under sufficient and insufficient nitrogen:genetic morphologic yield components. Iraqi Journal of Agricultural Sciences, v.37, n.3, p.67-74, 2006.

Bahrani, I. Q. M. Effect of phosphate soluble bacteria and humic acid in phosphorus equilibrium, nutrient readiness and maize (Zea mays L.). Baghdad: College of Agriculture University of Baghdad, 2015. 155p. Ph.D. Dissertation.

Bashan, Y.; de-Bashan, L.E. Microbial populations of arid lands and their potential for restoration of deserts.In: Dion, P. (Ed.). Soil biology and agriculture in the tropics. Berlin: Springer, 2010. p.109-137. (SOILBIOL, volume 21). https://doi. org/10.1007/978-3-642-05076-3_6.

Devi, N.L.; Mani, S. Effect of seaweed saps Kappaphycus alvarezii and Gracilaria on growth, yield and quality of rice. Indian Journal of Science and Technology, v.8, n.19, p.1-6, 2015. https://doi.org/10.17485/ijst/2015/v8i19/47610.

Kightlinger, K. W.; Chen, K.; Crunkleton, W. D.; Price, G.; Johannes, T. Effects of algae extract on the growth and metabolism of various microorganisms. In: AIChE Annual Meeting, 2012, Pittsburg. Proceedings... Pittsburg: American Institute of Chemical Engineers, 2012.

Lotze, E.; Hoffman, E.W. Nutrient composition and content of various biological active compounds of three South Africanbased commercial seaweed biostimulants. Journal of Applied Phycology, v.28, p.1379-1386, 2016. https://doi.org/10.1007/ s10811-015-0644-z.

Malusà, E.; Pinzari, F.; Canfora, L. Efficacy of biofertilizers: challenges to improve crop production. In: Singh, D. P.; Singh, H. B.; Prabha, R. (Eds.). Microbial inoculants in sustainable agricultural productivity. v.2, functional applications. Cham: Springer, 2016. p.17-40. https://doi.org/10.1007/978-81-3222644-4_2..

Mnajid, M. H.; Oiyed, A. A.R. Effect of addition of potassium fertilizer levels to soil and spraying of iron in growth and yield of corn (Zea mays L.). Tikrit Journal for Agricultural Sciences, v.13, n.2, p.398-405, 2013. https://www.iasj.net/ iasj/article/78571. 22 Jun. 2020.

Mohana, A. A.; Suleiman, M. M.; Khedr. W. S. Effect of humic acid and rates of nitrogen fertilizer on yield and yield components of corn (Zea mays L.). Jordan Journal of Agricultural Sciences, v.11, n1, p.229-241, 2015. https://journals.ju.edu.jo/JJAS/ article/view/8604/4351. 22 Jun. 2020.

Mohanty, D.; Adhikary, S. P.; Chattopadhyay, G. N. Seaweed liquid fertilizer (SLF) and its role in agriculture productivity. The Ecoscan, v.3, n. special, p.23-26, 2013. https://www. researchgate.net/publication/235430009. 22 Jun. 2020.

Mohanty, D.; Adhikary, S.P. Standardization of protocol for preparation of liquid extracts from seaweeds, quantification of their phytohormones and application for crop improvement. Indian Journal of Geo Marine Science, v..47, n.7, p.1364-1372, 2018. http://nopr.niscair.res.in/handle/123456789/44618. 22 Jun. 2020. 
Pal, A.; Dwivedi, S.K.; Maurya, P.K.; Kanwar, P. Effect of seaweed saps on growth, yield, nutrient uptake and economic improvement of maize (sweet corn). Journal of Applied and Natural Science, v.7, n.2, p.970-975, 2015. https://doi.org/10.31018/jans.v7i2.716.

Sharifi, R. S.; Taghizaden, R. Response of maize (Zea mays L.) cultivars of different levels of nitrogen fertilizer. Journal of Food Agriculture and Environment, v.7, n.3-4, p.518-521, 2009. https://www. wflpublisher.com/Abstract/2652. 22 Jun. 2020.

Singh, S.; Singh, M. K.; Pal, S. K.; Thakur, R.; Zodape, S. T.; Ghosh, A. Use of seaweed sap for sustainable productivity of maize. The Bioscan, v.10, n.3, p.1349-1355, 2015. https://www.researchgate. net/publication/297544547. 22 Jun. 2020.

Steel, G.D.; Torrie, J. H. Principles and procedures of statistics. 2.ed. New York: Mc Graw.Hill, 1980. 633p.
Wang, Y.; Fu, F.; Li, J.; Wang, G.; Wu, M.; Zhan, J.; Chen, X.; Mao, Z. Effects of seaweed fertilizer on the growth of Malus hupehensis Rehd. seedlings, soil enzyme activities and fungal communities under replant condition. European Journal of Soil Biology, v.75, p.1-7, 2016. https://doi.org/10.1016/j. ejsobi.2016.04.003.

Wuhaib, K.M.; Al-Haidary, H. K.; Makyia, K.A. Split application nitrogen for (Zea mays L.) genotypes to get the best sink. Tikrit Journal for Agricultural Sciences, v.9, n.1, p.104-116, 2009. https://www.iasj.net/iasj/article/20592. 22 Jun. 2020.

Zhang, X.; Ervin, E.H. Impact of seaweed extract-based cytokinins and zeatin riboside on creeping bentgrass heat tolerance. Crop Science, v.48, n.1, p.364-370, 2008. https://doi.org/10.2135/ cropsci2007.05.0262. 